\title{
UKRAINE'S FOREIGN TRADE WITH THE EU: OPPORTUNITIES AND CHALLENGES
}

\begin{abstract}
The article casts light onto the current state of foreign trade between Ukraine and the EU in the conditions of a free trade area. Having analyzed the structure of merchandise exports and imports, the author reveals major challenges that arise as current tendencies persist into the future. Special attention is paid to seizing the opportunities provided by the EU-Ukraine Free Trade Agreement for realization of export potential of the agricultural sector on the markets of these countries. The author suggests ways to create conditions for diversification of merchandise exports, facilitation of access to European markets for the exporters of finished agricultural goods, as well as taking measures for constraining the inflows of non-critical merchandise imports, in particular pharmaceutical products.
\end{abstract}

\section{Key words:}

Foreign trade, free trade agreement, exports, agricultural sector, EU countries.

(C) Halyna Artamonova, 2019.

Artamonova Halyna, Candidate of Economic Sciences, Assistant Professor, National University of Food Technologies, Ukraine. 
JEL: F10, F13, F68.

\section{Setting the problem}

The prospects for the development of Ukraine's foreign trade are currently determined by how successful it is in adapting to constantly changing environment of international economic relations.

This is the context, in which it is worth to consider the development of Ukraine's foreign trade relations with its current foreign partners, in particular the reorientation of Ukraine's exports towards the common EU market with seizing the opportunities provided by the Association Agreement and the free trade area (FTA) with the EU. At the same time, it requires the introduction of essential macroeconomic principles and public policy targets, the implementation of European standards and technical norms, the creation of common «value chains" by the EU countries, the imports of advanced production technologies, etc.

Even today, the national economic community continues to debate on the opportunities and threats brought in by the FTA with the EU: Some experts highlight only its positive effects, other experts point out that Ukraine inadequately uses all the opportunities offered by open markets of the EU, whereas others agree that the improved EU-Ukraine trade dynamics is only temporary in nature and may change at any point in time leading to worsening foreign trade balance in case protection measures are imposed on major exports from Ukraine.

Tracking the current state of foreign trade relations between Ukraine and the EU in the conditions of an FTA is an important task with a view to strengthening the positive results and finding ways to resolve urgent problems in this area. Such information is extremely important for shaping an effective public policy aimed at both full utilization of opportunities offered by the Agreement and mitigation of risks and challenges related to its implementation. The future development and strengthening of foreign trade cooperation should come into play on the economic, social and political situation of Ukraine.

Another urgent task is to realize the export potential of agricultural products (which currently make the largest share of Ukraine's exports to the EU) on the EU markets thanks to trade preferences that induce growth of the national markets for grain, oil and fruits and create a basis for development of the meat sector and, later, the dairy complex of Ukraine. 


\section{Review of recent literature}

The problems of research on Ukraine's European integration and trade and economic relations with the EU are highlighted in the works of many Ukrainian scientists, in particular Bazhenova (2019), Haidutskyi (2013), Heyets (2010), Kasych (2015), Nepriadkina (2018), Melnyk (2013), Yarosh-Dmytrenko (2017), and others. Paying due respect to advances in foreign trade research performed by Ukrainian scientists, there remains a need for an in-depth analysis of the tendencies in foreign trade between Ukraine and the EU after implementation of the FTA in the context of shifting product and geographical structure of merchandise exports, review of usage of EU's annual tariff quotas on Ukrainian products, especially agricultural products and foods, which account for almost one third of total merchandise exports; the dynamics and structure of imports from the EU, which affect the trade balance and shapes the dynamics and quality of economic growth in Ukraine.

\section{Setting the goal of the article}

The main goal of this work is to identify the tendencies in foreign economic relations between Ukraine and the EU in the context of FTA implementation.

\section{Main Findings}

The Association Agreement between Ukraine and the EU is the largest package of agreements in the history of independent Ukraine. The economic part of the Agreement covers major sectors and industries of the economy, which, if successfully implemented, will substantially approximate the economic system of Ukraine to that of the European Union based on mutual liberalization of the movement of goods, capital and services and harmonization of a significant part of Ukraine's legislative framework with norms and practices established in the EU'.

In January 2016, the implementation of the trade part of the EU-Ukraine Association Agreement was launched. Title IV «Trade and Trade-Related Mat-

\footnotetext{
${ }^{1}$ Report on implementation of the Association Agreement between Ukraine and the European Union in 2018. Retrieved from https://eu-ua.org/sites/default/files/ inline/files/ association-agreement-implementation-report-2018.pdf. (in Ukrainian).
} 
ters» was supposed to take effect at the end of 2014, but due to opposition from Russia its launch was delayed in order to hold tripartite consultations (Delegation of the European Union to Ukraine, n.d.).

The provisions of the EU-Ukraine Association Agreement are not reduced solely to setting zero tariffs in bilateral trade. In addition, Ukraine should implement European technical standards, phytosanitary rules and other regulations with respect to safety of manufactured goods and food products (Delegation of the European Union to Ukraine, n.d.).

All these changes have certainly brought in shifts in the geographical structure of export and import flows between Ukraine and the EU: The analysis of statistical data (Figure 1) shows that, since 2014, the EU's share has considerably grown in both Ukraine's overall merchandise exports (from $31.5 \%$ to $42.6 \%$ in 2018) and imports (from $38.7 \%$ to $40.6 \%$ in 2018).

Figure 1

\section{Dynamics of EU share in Ukraine's foreign merchandise trade}

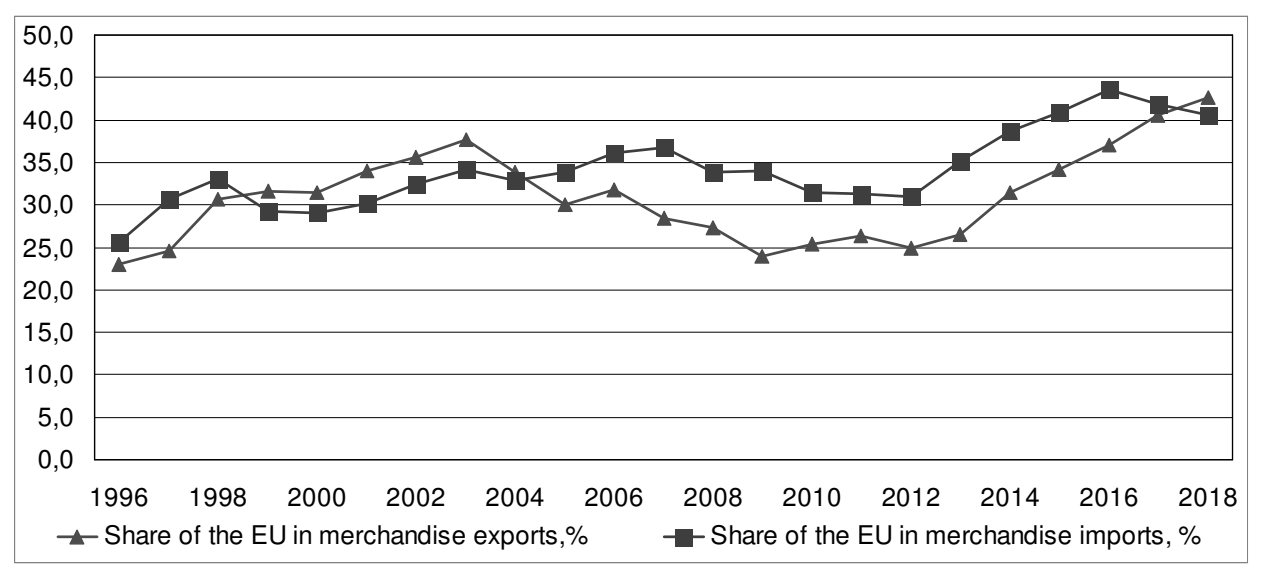

Source: Developed by the author based on data of State Statistical Service of Ukraine (2019). 

opportunities and challenges

On the whole, the highest growth of Ukrainian merchandise exports in 2018 was observed for the EU countries (a 15\% increase from 2017) compared to other regions $(+5.6 \%)$, which suggests a reorientation of domestic producers towards European markets. However, the rate of growth has slowed down compared to 2017 (Table 1). At that, it is worth to note that the deficit of trade with this region has decreased $(-6.3 \%$ from 2017$)$ (State Statistical Service of Ukraine, 2005).

Table 1

The dynamics of foreign merchandise trade with the EU

\begin{tabular}{|l|c|c|c|c|c|}
\hline \multirow{2}{*}{\multicolumn{1}{|c|}{ Indicator }} & 2016 & 2017 & 2018 & \multicolumn{2}{c|}{ YoY change, \% } \\
\cline { 2 - 6 } & \multicolumn{3}{|c|}{ USD million } & $2017 / 2016$ & $2018 / 2017$ \\
\hline Foreign Trade Turnover & 30637.1 & 38332.8 & 43373.5 & 25.1 & 13.1 \\
\hline Exports & 13496.3 & 17533.4 & 20157 & 29.9 & 15 \\
\hline Imports & 17140.8 & 20799.4 & 23216.5 & 21.3 & 11.6 \\
\hline Balance & -3644.5 & -3266 & -3059.5 & -10.4 & -6.3 \\
\hline
\end{tabular}

Source: Calculated by the author based on data of State Statistical Service of Ukraine (2019a).

This tendency was observed in 2019 as well. Thus, exports to the EU countries increased by USD 251 million in Q1 2019. However, the share of EU countries in Ukraine's total exports decreased to $38.3 \%$ (39.0\% in JanuaryMarch 2018). Over this same period, the highest change in the volume of imports into Ukraine was observed for the EU with USD 628 million (+13.8\%) compared to other regions. Also, the EU increased their share in total imports to Ukraine (from $36.4 \%$ to $38.8 \%$ ) (State Statistical Service of Ukraine, 2005).

Moreover, the statistical data show (Table 1) that the reorientation of domestic producers towards the European market has become more pronounced in 2018.

The recent years were marked by the processes of de-industrialization of exports and escalation of their agrarian specialization. The domestic economy continues to establish itself in the international markets as a key agrarian player. In 2014-2018, food products and agricultural raw materials finally established themselves as the basis for Ukrainian exports, reaching 34\% in 2018 (and 38.3\% in QI 2019) of exports compared to 12.8\% in 2007 (State Statistical Service of Ukraine, 2019b). At the same time, the successful entry of agricultural producers into foreign markets comes against the backdrop of large-scale de- 
industrialization of merchandise exports. Metallurgical products now account for only $26.3 \%$ of exports ( $44.5 \%$ in 2007 ), whereas the share of technological machine-building products in total exports is 6.9\% (16.4\% respectively) (State Statistical Service of Ukraine, 2019b).

At the same time, the increasing share of foods and agricultural raw materials in exports $(22.9 \%$ and $19.1 \%$ respectively in 2016 ; and $24.6 \%$ and $17.4 \%$ respectively in the 1st quarter of 2019) limits the ability of Ukraine to ensure its foreign economic security in view of the fact that traditional market risks that are typical for all raw commodity trade are coupled with risks of continuous prohibitions and limitations on access to foreign agricultural markets, most of which have strong protective tariffs and other barriers.

Contrary to trends in exporting, the structure of Ukrainian imports in 2018 shows an increased share of machine-building products (from 28.9 to $30.6 \%$ in Q1 2019), whereas the share of mineral products decreased to $24.8 \%(20.3 \%$ in Q1 2019) (State Statistical Service of Ukraine, 2019b). And traditionally, chemical products were the third largest group of imports (12.3\% in 2018). The overall share of these product groups has remained virtually unchanged over the last decade, reaching 66\% in 2018 (65.7\% in Q1 2019).

In view of this, an important issue today is the commodity structure of exports and imports between Ukraine and the EU. As Figure 2 shows, since 2016 almost no changes have been observed in the structure of merchandise exports to the EU. As before, in terms of trade volume, the top five exported products from Ukraine to the EU were agricultural products, metals, mineral products, and machinery (State Statistical Service of Ukraine, 2019a).

Ukrainian agricultural products are purchased most actively by the Netherlands, which account for $15.5 \%$ of total exports, Poland $-14.5 \%$ and Italy $13.8 \%$. Ten EU countries purchase $90 \%$ of total food exports. In 2018 , exports increased to the majority of these countries, except for France (due to decreased sales of oil and rapeseed), Romania (due decreased sales of sugar) and Bulgaria (sunflower oil). The Netherlands hold top position in terms of exports of food products, primarily due to a significant increase in purchases of rapeseed, soybeans and corn. Also, a significant increase was observed in export sales of poultry meat (2.4 times in 2017) and butter (4.2 times in 2017), although their share remains rather small.

In 2017-2018, exports to Europe were growing at a high rate thanks to both physical volumes and favorable prices. In particular, food export growth was mainly driven by an increase in physical volumes, whereas exports of metallurgical products grew thanks to favorable prices (Yevropeiska Pravda, 2017). 
Figure 2

\section{Main product groups of Ukrainian exports to the EU countries}

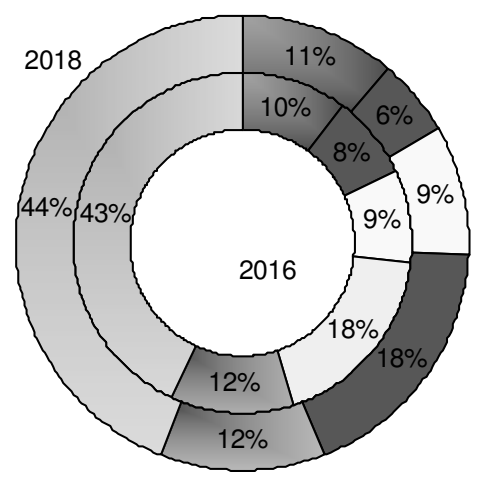

$\square$ Cereals (10)

$\square$ Animal or vegetable fats and

oils (15)

$\square$ Ores, slag and ash (26)

$\square$ Iron and steel (72)

$\square$ Electrical machinery (85)

$\square$ Other products

Source: Developed by the author based on data of State Statistical Service of Ukraine (2019a).

Throughout this period, the exports of «specific» food products (blueberries and cranberries, jam and jams, snails and shellfish, beeswax, roses, etc.) have grown. Exports of wood and wood products and furniture exhibited dynamic growth. Despite relatively small volumes, exports of certain types of machinebuilding products (wires, batteries, water heaters) increased; however, their dynamics remains sensitive to one-off deals, which means that they are characterized by absence of long-term contracts.

One of the main advantages of EU FTA for Ukrainian companies is the ability to import and export certain amounts of goods at zero tariff rates. The quotas are used up in a matter of months. Thus, already in the middle of 2018, the annual quotas for exports of wheat, corn, apple and grape juice, malt, tomatoes, honey, and butter have been fully used up. On the other hand, Ukrainian producers of niche crops, as before, cannot provide sufficient volumes of exports to fill the duty-free quotas. For example, quotas for garlic, oats, sugar, mushrooms, processed milk products, and sugar syrups were not used up in full. Often this is due to the fact that companies are not ready to engage in the certified production of niche crops: As they have enough buyers domestically, they are not willing to obtain all the necessary permits to trade in the European market (UCAB, n.d.). It should be added that the EU-Ukraine Association Agreement provides that the sizes of quotas should increase by $10 \%$ annually over a five-year period. 
It should also be noted that in 2018 the growth of agricultural exports slowed down, the rate of its growth decreased. Industrial goods, in particular, metal products, machinery and equipment, exhibited the greatest growth in sales. Several factors worked here: A decrease in the supply of cereals and sunflower oil due to decreased harvests in the previous year, and the fact that Ukrainian companies are gradually starting to produce products that meet the expectations of European buyers. One example is an increase in the exports of automobile spark plugs. The sales of these products in the EU increased by one-forth, thus becoming the largest product group in exports after corn as measured in value terms. This became possible after attracting investment to enterprises which produce spare parts for vehicles. Since 2015, nine new car cable manufacturing plants have been opened in Ukraine, and several more are under construction. However, as before, the EU demonstrates demand only for those Ukrainian goods, the production of which involves manual labor, but not technology (such as the production of car cables, where "technology» is reduced to manual twisting of wires and fastening them with plastic ties). Ukraine does not yet export «real» technological products. Enterprises which sell high-technology finished goods such as drones and electric bicycles to the European Union are only small startups that export small batches of goods (Yevropeiska Pravda, 2017).

It is worth to note that the products, which generate foreign exchange revenues for Ukrainian enterprises, include furniture and textile clothes. This is a great success for small and medium-sized enterprises (SMEs). Unfortunately, no statistical data are available on foreign economic activity by size of enterprises, but we can infer that the share of SMEs in exports has increased significantly over the last three years.

Thus, on the whole, Ukrainian business already benefits from the introduction of Free Trade Area with the EU thanks to:

- the reduction of customs barriers (over $98 \%$ of customs duties on both sides were removed). This is why goods and services imported from the Single Market of the EU become cheaper in result of removal of customs tariffs; Ukrainian goods are not subject to customs duties when exporting to the EU;

- the harmonization of business conditions between Ukraine and the EU by way of harmonization of legislation. Thus, this gives rise to competition between Ukrainian and EU businesses within convergent legal frameworks, and moreover, changes are taking place in the functions and work of some Ukrainian regulatory bodies so as to bring them closer to regulatory standards of the EU;

- the use of new partner search tools, such as the European Enterprise Network (EEN); 
- the use of EU tools and mechanisms for the development of small and medium-sized enterprises (COSME);

- the alternative market, given the difficulty of access to traditional markets;

- the simplification of attracting technological and innovative solutions from the EU countries;

- improved access to high-quality technologies, seeds and plant protection products;

- the application of zero tariff rate quotas (TRQs) to imports of products into the EU (for specific product categories) (Bazhenova, 2019).

For the country as a whole, the implementation of European standards and requirements is an advantage, which will encourage Ukrainian producers to increase the quality of produced domestic goods. In its turn, improving the quality of goods in the domestic market contributes to international competitiveness of Ukrainian products, which creates the potential for increasing exports not only to the EU, but also to other countries.

Thus, our analysis proves that the prevalence of raw materials, including a large share of agricultural products, in Ukrainian exports creates significant risks in view of the fact that commodities are sensitive to conjunctural changes in market conditions and to introduction of various protective measures by trading partner countries.

The Ukrainian government and producers cannot directly influence upon the process of tariff quota distribution because the established procedure defines that it is importing companies from the EU countries who initiate the application of these tariff quotas as they have the right to submit an application for imports to their governments. Subsequently, such applications are registered with the European Commission ${ }^{2}$. Thus, the task of Ukrainian sellers is to find a potential buyer in the EU who could organize the submission of the relevant application, whereas the task for the Government of Ukraine is to create the most favorable conditions for domestic producers to find potential buyers. In this regard, it is particularly desirable to create a database of potential buyers, which will simplify the process of searching for domestic business partners in the EU countries.

Also, taking into account that quotas for agricultural products are used up during the first several months of the year, there is a need in both increasing the size of quotas and improving their administration. It will be possible to achieve this goal by holding negotiations with the EU based on adequate mathematical calculations.

\footnotetext{
${ }^{2}$ The Eurointegration Portal. (n.d.). Free Trade Area. Retrieved from: https://eu-ua.org/ zona-vilnoi-torhivli. (in Ukrainian).
} 
Another challenge for Ukraine in its foreign trade with the European Union is a significant deficit of bilateral trade, which exerts pressure on the balance of payments and the value of national currency. In this respect, it is necessary to analyze the dynamics of European imports and its structure.

When considering the structure of merchandise imports from the EU, we can observe a tendency towards increasing volumes of imported gas and machine-building products, which makes Europe the leading importer of goods into Ukraine with its share in total imports increasing to $41 \%$ in 2018. In particular, European countries account for almost half of total imported machine-building products (State Statistical Service of Ukraine, 2019a). An increase in imports is driven by high demand on the side of agricultural producers (in particular, the demand for agricultural machinery, such as tractors from Germany and France, insecticides and fertilizers), as well by rising consumer demand (in particular, for passenger cars, which was induced by easement of the tax burden).

The structure of Ukraine's agri-food imports shows that the largest volume of imports $(6.2 \%$ in 2018$)$ is finished foods, in particular fish and crustaceans (frozen fish), various foods, oilseeds, coffee, and tea. Their overall share is almost half the value of all agricultural imports.

Figure 3

Main product groups of Ukrainian imports from the EU

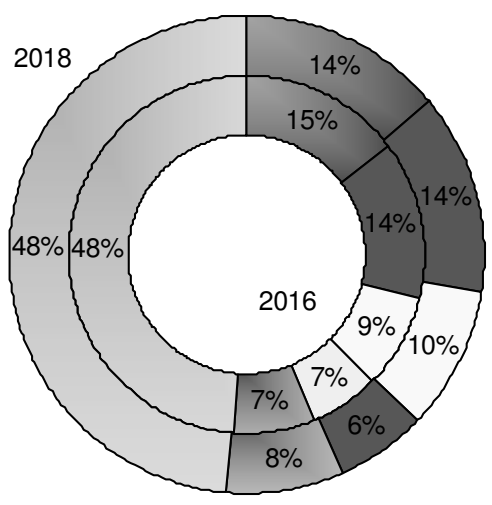

\author{
$\square$ Mineral fuels, mineral oils and \\ products of their distillation (27) \\ $\square$ Boilers, machinery (84) \\ $\square$ Vehicles, other than railway \\ (87) \\ $\square$ Pharmaceutical products (30) \\ $\square$ Electrical machinery and \\ equipment (85) \\ $\square$ Other products
}

Source: Developed by the author based on data of State Statistical Service of Ukraine (2019a). 

opportunities and challenges

Ukraine has started to remove import duties on imports from the EU since January 1, 2016, that is since the launch of Free Trade Area between Ukraine and the EU. For individual, "sensitive» commodity groups, Ukraine applies a gradual reduction / cancellation of import duties on imports originating from the EU within the framework of FTA between Ukraine and the EU during transition periods of 3 to 10 years (Annex I-A of the Association Agreement). Ukraine also set duty-free tariff quotas for 3 types of goods (pork meat, poultry meat and sugar) and provided additional volumes for two of them (Ministry of Economic Development and Trade, n.d.).

According to analysis of the data compiled by the State Statistical Service of Ukraine (2019), the negative trade balance between Ukraine and the EU is primarily caused by gas, oil, petroleum products, vehicles and pharmaceuticals. Thus, if Ukraine did not import medicines and gas from the EU, it would instantly transform the trade balance with the EU into a positive one. But there is an objective situation that only a new state policy can change.

Thus, the performed analysis suggests that the situation with trade between Ukraine and the EU does not seem to be absolutely straightforward. First of all, despite the fact that exports to the EU countries increase, their commodity structure continues to include predominantly raw materials and low-technology products, thus creating risks related to price and market fluctuations. Second, the reduction of EU import duties did not lead to significant changes in the structure of foreign trade: Raw material imports from Ukraine and high-tech EU exports. Third, the continuing negative trade balance by most product groups adversely affects the balance of payments and economic growth.

\section{Conclusions}

Thanks to the implemented Free Trade Agreement, the European Union is nowadays the leading trade partner of Ukraine. However, in spite of some positive developments, Ukraine's deficit of bilateral trade in goods with the EU persists due to a large share of high-value-added products in its overall imports, whereas the expansion of Ukrainian exporters into the new markets is hampered by a lengthy and capital-intensive process of bringing Ukrainian products in conformity with European standards. This problem could likely be solved by enhancing export-oriented product adaptation not only for raw materials, but also for high-value-added products manufactured by food processing industry. It would also be feasible to speed up the diversification of meat and dairy exports, which has previously been supplied to the Russian market. 
Ukraine suffers from both exports and imports of raw materials. Excessive dependency on these flows makes the country vulnerable to additional threats of possible recession in the European Union and rising energy prices.

In order to promote growth of Ukrainian merchandise exports to the EU, it is necessary to improve the administration of trade operations between Ukraine and the EU by means of reducing the costs of exporting for domestic producers, to increase the size of quotas, to defend the interests of Ukrainian exporters at European institutions, and to reduce the supply of non-critical imports.

\section{References}

1. Balezhentis O., Yatsenko O. (2018). The asymmetries of trade integration of Ukraine. International Economic Policy, 1, 28. Retrieved from http://iepjournal.com/journals/28/2018_2_Basenentius_Yatsenko.pdf (in Ukrainian).

2. Bazhenova O., Bochi A., Povoroznyk V. (2019). The Impact of the EUUkraine Deep and Comprehensive Free Trade Area on the Ukrainian Industrial Sector. Democracy House. Retrieved from http://library.fes.de/pdffiles/bueros/ukraine/15250.pdf.

3. Haidutskyi, P. (2013). Ukraine-the EU: The problems of integration. Dzerkalo Tyzhnia, 20 (in Ukrainian).

4. Delegation of the European Union to Ukraine. (n.d.). The EU-Ukraine: Deep and Comprehensive FTA. Retrieved from http://eeas.europa.eu/ archives/ delegations/ukraine/documents/virtual_library/dcfta_guidebook_web.pdf (in Ukrainian).

5. Heyets, V. M. (Ed.). (2010). A New Course: Reforms in Ukraine in 20102025. National Report. Kyiv, Publishing Centre of National Vernadskyi Library of Ukraine (in Ukrainian).

6. Kasych, A. O., Tsokalo, O. A. (2015). The state and prospects for trade relations between Ukraine and the countries of the European Union. Naukovyi Visnyk Khersonskoho Derzhavnoho Universytetu. Ekonomichni Nauky, 13, 3 , 23-28 (in Ukrainian).

7. Melnyk, T. M., Holovachova, O.S. (2013). Tariff regulation of trade in agricultural products of Ukraine in the context of Eurointegration. Ekonomichyni Prostir, 80, 521. Retrieved from http://nbuv.gov.ua/UJRN/ecpros_2013_80_3 (in Ukrainian).

8. Ministry of Economic Development and Trade (n.d.). The cooperation between Ukraine and the European Union. Retrieved from http://me.gov.ua/ Tags/DocumentsByTag?lang=uk-UA\&id=10ca8da3-169d-419b-a6f2-d42635f 92b8b\&tag=SpivrobitnitstvoMizhUkrainoiuTaYevropeiskimSoiuzom (in Ukrainian). 

opportunities and challenges

9. Nepriadkina, N. V. (2018). The peculiarities and prospects for the development of foreign trade of Ukraine and the EU in agricultural products. Naukovyi Visnyk Kharkivskoho Derzhavnoho Universytetu Imeni V. H. Karazina. Seria: Mizhnarodni Vidnosyny. Ekonomika. Krainoznavstvo. Turyzm, 7, 60-65. Retrieved from http://nbuv.gov.ua/UJRN/VKhMv_2018_7_11 (in Ukrainian).

10. Report on implementation of the Association Agreement between Ukraine and the European Union in 2018. Retrieved from https://eu-ua.org/ sites/default/files/inline/files/association-agreement-implementation-report2018.pdf (in Ukrainian).

11. State Statistical Service of Ukraine. (2019a). Commodity structure of foreign trade with the EU countries. Retrieved from http://www.ukrstat.gov.ua/ operativ/operativ2019/zd/tsztt_ES/tsztt_ES_u/tsztt_ES_3_19_u.htm (in Ukrainian).

12. State Statistical Service of Ukraine. (2019b). Commodity structure of foreign trade. Retrieved from http://www.ukrstat.gov.ua/operativ/operativ2019/zd/ tsztt/tsztt_u/tsztt0419_u.htm (in Ukrainian).

13. State Statistical Service of Ukraine (2005). The dynamics of geographic structure of foreign merchandise trade. Retrieved from http://www.ukrstat.gov.ua/ operativ/operativ2005/zd/zd_rik/zd_u/gs_rik_u.html (in Ukrainian).

14. Tariff quotas within the frames of DCFTA. Retrieved from http://www.me.gov.ua/Documents/Detail?lang=uk-UA\&id=f5cea3c3-d7e04e49-994d-f87089e3d3fc\&title=TarifniKvotiVRamkakhPvzvt (in Ukrainian).

15. The Eurointegration Portal. (n.d.). Free Trade Area. Retrieved from: https://eu-ua.org/zona-vilnoi-torhivli (in Ukrainian).

16. UCAB. (n.d.). The Free Trade Area with the EU: Results of 2018. Retrieved from http://ucab.ua/ua/pres_sluzhba/novosti/zona_vilnoi_torgivli_z_es_pidsumki_2018_roku (in Ukrainian).

17. Yarosh-Dmytrenko, L. O. (2017). Foreign trade relations of Ukraine with countries of the European Union in the context of integration into the European economic space. Naukovyi Visnyk Mizhnarodnoho Humanitarnoho Universytetu. [Seriia: Ekonomika I Menedzhment], 25, 1, p. 48-52. Retrieved from http://nbuv.gov.ua/UJRN/Nvmgu_eim_2017_25(1)_12 (in Ukrainian).

18. Yevropeiska Pravda (2017). What changed in Ukrainian economy after the Association Agreement. Retrieved from https://www.eurointegration.com.ua/ articles/2017/05/18/7049377/ (in Ukrainian). 